\title{
DESENVOLVIMENTO E QUALIDADE DE VIDA; LIMITAÇÕES NA UTILIZAÇÃO DOS INDICADORES DO CRESCIMENTO ECONÔMICO
}

\author{
Carlos F. F. Lobo*
}

As diferenças existentes entre as condições de vida nas diversas regiões do mundo há bastante tempo vêm merecendo destaque nas discussões políticas internacionais. As ditas teorias do desenvolvimento, inicialmente organizadas nos trabalhos da economia clássica, ganharam grande força, sobretudo a partir de finais do século XVIII. Em geral, a ampliação das diversas formas de renda e riqueza passou a compor os critérios de definição e as formas de mensuração do desenvolvimento. Os sistemas de contabilidades nacionais, representados por inúmeros agregados econômicos, passaram a integrar os variados indicadores econômicos utilizados.

No entanto, a partir de meados do século passado, um arsenal crítico começa a minar os pilares de sustentação das tradicionais teorias de desenvolvimento econômico. A Conferência de Estocolmo, o Relatório Brundland e a ECO 92, ao buscar incorporar os vários setores da sociedade na discussão sobre os diversos aspectos $\mathrm{da}$ chamada "problemática ambiental”, romperam com alguns rígidos preceitos prevalecentes. A utilização de conceitos como eco desenvolvimento e desenvolvimento sustentável passou a representar alguns dos prováveis limites que se impunham à incessante busca pelo crescimento econômico. A preservação das diversas formas de vida na Terra tornou-se uma das mais novas preocupações internacionais, que até então havia despertado pouco interesse.

Atualmente, um número bastante expressivo de intelectuais e instituições de pesquisa em todo o mundo buscam traçar novos rumos às antigas propostas, anteriormente centrados na ideia de crescimento da produção e do consumo. Edificado na obra de autores como Amartya Sen e Mahabud Ul Haq, o conceito de desenvolvimento humano também surge como uma proposta alternativa. A ampliação das potencialidades e possibilidades de realização humana tem sido apresentada como o grande desafio da humanidade. O combate

\footnotetext{
* Mestre em Geografia, Professor do Centro Universitário de Belo Horizonte (UNI-BH) e Professor municipal lotado na Gerência de Informações Técnicas da Secretaria Municipal da Coordenação da Política Social.
}

Cadernos do Leste

Artigos Cientificos

Belo Horizonte, Edição Especial, 2000 a 2008 
às chamadas privações elementares, como propõem os defensores dessa proposta, deve ser entendido como um dos pontos cruciais no processo de desenvolvimento humano.

Nesse contexto, passa a ser um crescente o número de indicadores sociais produzidos, como o já bastante conhecido Índice de Desenvolvimento Humano (IDH). A própria divulgação de expressões como qualidade de vida e sustentabilidade ambiental representa uma abertura teórica/conceitual, o que tem permitido um alargamento das dimensões utilizadas nos instrumentais metodológicos. Contudo, mesmo diante desse processo de redefinição, antigos preceitos ainda persistem na análise acerca do processo de desenvolvimento. A ampliação das bases econômicas ainda continua sendo considerada fundamental à melhoria nas condições de vida das populações.

\section{1- CONTRIBUIÇÕES DA TEORIA ECONÔMICA CLÁSSICA}

Um dos precursores na construção teórica acerca do desenvolvimento econômico foi certamente o britânico Adam Smith ${ }^{1}$. Em uma de suas principais obras, Um Inquérito sobre a Natureza e a Causa da Riqueza das Nações, publicada em 1776, ao enfatizar o princípio da divisão do trabalho para obter incremento das energias produtivas, Smith procurava identificar os fatores econômicos responsáveis pela formação e expansão da riqueza nacional. Uma maior divisão do trabalho e especialização conduz ao aumento da destreza dos trabalhadores, à redução do tempo necessário à produção de bens e à invenção de melhores máquinas e equipamentos (Baldwin e Meier, 1968). O aumento no tamanho do mercado, dada a intensificação na divisão do trabalho, também facilita a redução dos custos médios de produção, gerando lucros e elevando os níveis de renda e emprego.

\footnotetext{
${ }^{1}$ É preciso salientar que vários trabalhos já haviam discutido acerca dos possíveis determinantes do processo de desenvolvimento econômico. Os chamados mercantilistas, por exemplo, tiveram significativa importância nesse debate. Para esse grupo de pensadores, a riqueza das nações dependia diretamente das trocas comerciais estabelecidas no mercado internacional, sobretudo no que diz respeito ao fluxo de metais preciosos. Outra corrente, que também obteve grande êxito, foi a chamada Escola Fisiocrata. Os economistas fisiocratas combatiam a doutrina mercantilista e propunham uma conduta liberal por parte do Estado, transferindo atenção do comércio para a produção, notadamente aquela referente ao setor agrícola (Souza, 1999).
}

Cadernos do Leste

Artigos Cientificos

Belo Horizonte, Edição Especial, 2000 a 2008 
Nesse sentido, conforme leitura de Souza (1999), Smith acreditava que o desenvolvimento ocorre mediante o aumento da proporção de trabalhadores produtivos em relação aos trabalhadores improdutivos, o que reduziria o desemprego e elevaria os índices gerais de renda da população. O trabalho produtivo fica fertilizado pelo capital, aumentando o valor do chamado produto total e a própria demanda interna, o que possibilita um maior volume de produção com menor custo e emprego de trabalho produtivo e capitais adicionais .

David Ricardo talvez seja o principal sucessor e discípulo de Smith. Em seus trabalhos, Ricardo também se preocupava com os fatores responsáveis pela formação da riqueza nacional, sobretudo através da distribuição entre capitalistas, trabalhadores e proprietários da terra. Para esse autor, conforme análise de Souza (1999), o empecilho ao crescimento econômico se encontra na agricultura, incapaz de produzir alimentos baratos para o consumo dos trabalhadores, o que forçava a elevação nos salários nominais. Assim, a função de produção ricardiana incorpora a hipótese de que o volume total de produção está sujeita à chamada produtividade marginal decrescente, originada pela incorporação de crescentes glebas de terras improdutivas (ou menos produtivas). Ricardo também acreditava que a elevação dos salários pressupunha a acumulação de capital e que a classe de proprietários de terras constituía um peso social crescente, o qual só poderia ser reduzido mediante uma política de livre importação (Furtado, 1983).

Em seu amplo trabalho, Marx oferece interpretações distintas daquelas defendidas por Smith e Ricardo. Apesar de não se concentrar especificamente sobre o conceito e as definições de desenvolvimento econômico, como ressalta Furtado (1983), esse autor obteve grande mérito ao introduzir a teoria econômica como fundamento de sua teoria da história. Se para os clássicos o problema da distribuição estava na relação entre capitalistas e proprietários de terras, para Marx o conflito ocorre entre capitalistas e trabalhadores. Os primeiros eram os proprietários dos meios de produção e os últimos dispunham somente de sua força de trabalho. No sistema capitalista, a oferta disponível de trabalho e os meios de subsistência são capazes de gerar uma corrente de bens superior à necessidade para manter a oferta de trabalho e o estoque de equipamentos (Baldwin e Meier, 1968). Essa diferença entre o trabalho empregado e a necessidade de reprodução do capital é o que Marx chamava de Cadernos do Leste Artigos Cientificos 
mais-valia. A teoria da mais-valia é um dos pontos centrais na obra desse autor, sobre a qual se baseia sua análise a respeito do desenvolvimento econômico. Marx considerava que o desenvolvimento efetuava-se de forma caótica e com um eminente conflito distributivo. Enquanto o progresso técnico produz períodos de prosperidade, as contradições internas inerentes ao modo de produção capitalista promovem crises cada vez mais prolongadas, o que culminaria com a derrocada do próprio sistema.

\section{2- AS ABORDAGENS E CRÍTICAS INICIADAS A PARTIR DO PENSAMENTO NEOCLÁSSICO}

Conforme Baldwin e Meier (1968), por volta de 1870 há uma nítida guinada nas principais correntes do pensamento econômico. Nesta época, as grandes descobertas tecnológicas e os novos recursos do século XIX tornaram-se evidentes. Os salários reais se situavam bem acima do nível de subsistência, a taxa de lucros era alta e as rendas da terra traduziam o extraordinário aumento das rendas nacionais. Assim, o temor do suposto estágio estacionário, como havia sido proposto pelos clássicos, deixara de ser um assunto de interesse corrente $^{2}$. Os economistas neoclássicos, como ficaram mundialmente conhecidos, voltaram sua atenção principalmente para a distribuição da renda, ou a chamada teoria do equilíbrio geral. Para Alfred Marshall ${ }^{3}$, por exemplo, o desenvolvimento econômico ocorre de forma gradual e contínua, sendo movido pelo progresso técnico da indústria e pelas melhores oportunidades para intercâmbio de conhecimento (Baldwin e Meier, 1968). De acordo com Marshall, conforme Souza (1999), a harmonia individual produz a harmonia social. Ao Estado caberia a função de preservar essa estabilidade social, assegurando a liberdade individual e o direito de propriedade. O próprio mercado, como já havia sido proposto pelos clássicos, seria um eficiente regulador da economia.

\footnotetext{
${ }^{2}$ É importante frisar que apesar de os economistas clássicos terem se preocupado com o chamado estágio estacionário, Stuart Mill já apresentava uma visão otimista ao considerar a ação do progresso técnico. Para Mill, os aperfeiçoamentos na produção, advindos do avanço tecnológico, no comércio e nos serviços propiciam espaço e abrem campo para um aumento de capital e produção (Souza, 1999).

${ }^{3}$ Além de Marshall, outros nomes como Carl Menger, William Jevons, Léon Walras, Vilfredo Pareto, Allym Young, Gustav Cassel, sob a ótica da economia neoclássica, também destacaram-se nas formulações teóricas acerca do desenvolvimento econômico.
}

Cadernos do Leste

Artigos Cientificos

Belo Horizonte, Edição Especial, 2000 a 2008 
Enquanto os economistas neoclássicos preocupavam-se com a alocação eficiente dos recursos disponíveis, Keynes centrou sua análise na economia do pleno emprego (Souza, 1999). Ao combater o princípio de equilíbrio espontâneo posto pela escola neoclássica, presentes na chamada lei de $\mathrm{Say}^{4}$, Keynes empenhou-se em identificar os fatores determinantes presentes no princípio da demanda efetiva (Furtado, 1983). Se para os clássicos as leis do "livre mercado" promoviam um encadeamento automático entre aumento da produção e do consumo, o pensamento keynesiano atribuía ao Estado o papel principal na economia, reduzindo o desemprego, elevando a produção em direção a níveis gerais de pleno emprego ${ }^{5}$. Para esse autor, conforme interpretação de Souza (1999), o pleno emprego não é normalmente atingido, dada a insuficiência da demanda efetiva. A rigidez de salários e preços, ao contrário do que afirmavam os clássicos, constituía um ponto fundamental da abordagem Keynesiana. Os argumentos defendidos por Keynes tiveram grande repercussão a partir da $3^{\mathrm{a}}$ década do século XX, sobretudo em decorrência da contundente depressão econômica que atingiu quase indiscriminadamente todos os países do mundo à época. A chamada Crise de 29 foi um duro golpe nos pressupostos da economia clássica e nos princípios da Lei de Say. Ao invés do laissez-faire dos liberais, defendia-se uma ação mais efetiva e direta do Estado.

Em um de seus mais importantes trabalhos, A teoria do desenvolvimento, publicado originalmente em 1911, Joseph Shumpeter também incorporou novos aspectos aos pressupostos da economia clássica e neoclássica. Apesar de acreditar que o capitalismo podia proporcionar níveis sempre crescentes de rendas, esse autor rejeitava a hipótese de que o desenvolvimento ocorria de maneira gradual e contínua. Para Schumpeter, os avanços no produto nacional ocorriam através de saltos e repentes desarmoniosos quando se exploram horizontes de novos investimentos (Baldwin e Meier, 1968). Desta forma, Schumpeter acredita que o desenvolvimento se deve à presença de inovações tecnológicas, impulsionadas

\footnotetext{
${ }^{4}$ A chamada lei de Say refere-se, em síntese, ao pressuposto segundo o qual a oferta gera sua própria procura: ao produzir, um indivíduo torna-se consumidor de seus próprios produtos ou comprador e consumidor dos produtos de outro (ver Ricardo, In: Souza, 1999).

${ }^{5}$ Keynes apontou o problema da rigidez de salários, o que leva ao chamado desemprego involuntário, afetando o nível de demanda agregada. A redução na propensão marginal a consumir e investir também conduz a uma situação em que os investimentos não se mostram suficientes para elevar a demanda a um patamar desejável (Souza, 1999).
}

Cadernos do Leste

Artigos Cientificos

Belo Horizonte, Edição Especial, 2000 a 2008 
sobretudo pela ação de empresários empreendedores ${ }^{6}$. Nesse processo, o sistema de crédito bancário assume um papel fundamental. Novos investimentos em bens de capital, capacitação tecnológica e treinamento de mão-de-obra dinamizam a economia, gerando os chamados efeitos de encadeamento, assim como efeitos multiplicadores sobre o emprego e a renda. Nesses casos, o processo produtivo deixa de ser rotineiro, saindo do estágio estacionário que caracteriza o chamado fluxo circular (Souza, 1999). Assim, o desenvolvimento econômico traduzia-se por mudanças tanto quantitativas quanto qualitativas. Quando só há crescimento a economia funciona em um sistema de fluxo circular de equilíbrio, cujas variáveis econômicas crescem em função da expansão demográfica.

Outro importante nome nas formulações teóricas do desenvolvimento no século passado foi Rosenstein-Rodam. Ao analisar a situação nos países de baixa renda, esse autor percebeu que os investimentos são bastante escassos devido à falta de estímulos oferecidos por economias de mercados internos pouco expressivos. Essa insuficiência dos investimentos, a falta de motivação nas aplicações produtivas e a inexistência de uma infraestrutura apropriada tornam-se obstáculos diretos ao processo de desenvolvimento. Há, nesses casos, como defende Rosenstein-Rodam, a necessidade de adoção de um amplo projeto de investimentos, baseado em um modelo de crescimento equilibrado (Bastos e Silva, 1995). Posteriormente, Hirschmam rediscutiu a proposta esboçada por Rosenstein-Rodam, incorporando outros elementos à sua análise. De acordo com esse autor, um país deve seguir rumo ao crescimento não-equilibrado, haja vista que é o estado de desequilíbrio que põe em movimento as forças capazes de induzir o desenvolvimento econômico. Para Hirschmam, o desenvolvimento resulta dessa indução a investir, dada a geração de pressões, tensões e desequilíbrios. Esses desequilíbrios produzem os efeitos de encadeamento, aumentando a produtividade de outros setores da economia. Hirschmam também reconhece a necessidade da intervenção do Estado, o que deve contribuir para o aumento crescente nos investimentos.

Rostow também foi outro nome de grande repercussão. Para esse autor, o processo de desenvolvimento econômico ocorre através de etapas de crescimento. Em princípio, tem-

\footnotetext{
${ }^{6}$ Para Schumperter, as inovações podem ocorrer através da: “(1) introdução de um novo bem; (2) emprego de um novo método de produção; (3) abertura de um novo mercado; (4) conquista de uma nova fonte de matéria-prima e (5) reorganização de uma indústria qualquer". (ver Schumpeter, In: Baldwin e Meier, 1968, p.123).
}

Cadernos do Leste

Artigos Cientificos

Belo Horizonte, Edição Especial, 2000 a 2008 
se um período longo (um século ou mais) durante o qual são estabelecidas as condições prévias para a decolagem; em seguida ocorre a decolagem propriamente dita, que se define em duas décadas; e, por último, um período prolongado em que o crescimento se torna normal e relativamente automático. Para Rostow, a passagem de uma economia para o estado de desenvolvimento é marcada pelo crescimento dos investimentos, o que eleva o produto real per capita (Bastos e Silva, 1995). Esse estímulo pode ocorrer em virtude de mudanças institucionais, inovações técnicas ou variações nas relações de troca. Os países não desenvolvidos estariam, de acordo com Rostow, em etapas iniciais. Logo, o caminho para o desenvolvimento deveria passar pelo percurso seguido pelos países desenvolvidos ${ }^{7}$.

É importante frisar que essa idéia de atraso, presente na obra de Rostow, esteve intimamente ligada à própria imagem da chamada modernização ${ }^{8}$. Os ditos teóricos da modernização, pelo menos em um primeiro momento, como bem salientou Eisenstadt (1968), viam-na como um processo direcional de mudança de um primeiro estágio, o tradicional, para o estágio final, o moderno. Esse aspecto dinâmico-direcional, bem como a visão otimista subjacente à grande parte dos trabalhos sobre a modernização, centravam-se nas análises das características sociodemográficas e estruturais.

No entanto, a experiência vivida pelas sociedades latino-americanas nas últimas décadas do século XX, com o fortalecimento de regimes autoritários e autocráticos, mesmo diante dos positivos resultados quer em termos sociodemográficos, quer em termos de diferenciação e especificidade estruturais, levou a uma série de estudos a questionar o chamado "modelo" de modernização. A realidade vivida nesses países representava, de acordo com Eisenstadt (1968), não de casos de não desenvolvimento da modernização, mas

\footnotetext{
${ }^{7}$ Baldwin e Meier, como indica Singer (1977), nessa afirmativa, apontaram alguns aspectos que entravam o processo de desenvolvimento econômico. Esses autores acreditavam que o desenvolvimento ocorria mediante a seguinte situação econômica: (1) predomínio da produção primária, (2) pressão populacional, (3) escassez de recursos naturais, (4) população economicamente atrasada, (5) deficiência de capitais e (6) mercado voltado para o comércio exterior. Para decolar o processo de desenvolvimento dever-se-ia romper com o esse estágio, que caracteriza o chamado subdesenvolvimento. Nesse sentido, a tradição teórica econômica que predominava até pelo menos meados do século passado, como ressalta Furtado (1983), preocupou-se principalmente com algumas variáveis econômicas dos países ditos desenvolvidos. Em geral, a concepção teórica prevalecente, que vai de Marx a Hicks, de acordo com esse autor, elaborava uma explicação dos processos econômicos nos países mais avançados na industrialização, acreditando que seria suficiente para o entendimento do que ocorre nas economias de desenvolvimento retardado.

${ }^{8}$ É oportuno frisar que a idéia de modernização envolvia aspectos que iam além do crescimento ou desenvolvimento econômico. $\mathrm{O}$ conceito de modernização englobava fenômenos sociais e culturais, não necessariamente atingidos por transformações na base produtiva de uma determinada sociedade.
}

Cadernos do Leste

Artigos Cientificos

Belo Horizonte, Edição Especial, 2000 a 2008 
antes de colapsos de determinadas estruturas institucionais modernas, mesmo que em fases relativamente prematuras da modernização.

As questões levantadas por Eisenstadt, em boa medida, representaram a insatisfação dos vários trabalhos realizados pela intelectualidade dos países ditos periféricos. $\mathrm{Na}$ América Latina, o debate originado a partir dos trabalhos produzidos pela CEPAL, assim como seus próprios opositores, também contribuiu para o aprimoramento teórico necessário ao entendimento do processo de desenvolvimento econômico. A chamada crítica dualista, apesar de fortemente vinculada à economia clássica, foi um importante movimento de contestação da tradição econômica vigente.

\section{3- A CEPAL E O PENSAMENTO LATINO-AMERICANO}

Criada ao final da década de 1940, a Comissão Econômica para a América Latina (CEPAL), ao enfocar o caso específico dos países latino-americanos, lançou novas bases de interpretações sobre as possíveis causas do não desenvolvimento. Contrapondo-se, por exemplo, à idéia de que o subdesenvolvimento representava apenas um estágio transitório, ou, devido às leis das vantagens comparativas, propostas por David Ricardo, as análises cepalinas destacavam as desiguais relações de troca entre os países do centro e da periferia, alertando para a necessidade de investimentos para alavancar o processo de industrialização.

Um dos maiores expoentes do pensamento cepalino foi o economista argentino Raul Prebisch. Esse autor argumentava que a evolução das relações de troca no comércio internacional no século XX não se adequava aos postulados ricardianos das vantagens comparativas. O controle sobre a oferta de bens manufaturados possibilitava a manipulação de preços por parte dos países centrais, o que também trazia benefícios pela maior redução nos custos de produção e pelo incremento crescente de inovações tecnológicas. Assim, ainda de acordo com Prebisch, como esclarece Cardoso (1993), as relações econômicas entre o Centro e a Periferia tendiam a reproduzir ou agravar o enorme fosso existente entre os dois grupos de países. A alternativa apresentada pela CEPAL passava pelo investimento maciço no processo de industrialização, algo que deveria ser efetivado mediante a substituição das Cadernos do Leste Artigos Cientificos 
importações, fortalecendo o mercado interno. Era, portanto, o caminho mais seguro para os países ditos periféricos, o que reduziria a dependência em relação aos manufaturados exportados pelo centro, aumentando os níveis de renda e emprego criados pelo surgimento de novos mercados específicos.

As estratégias sugeridas por Prebisch, conforme Souza (1999, p.201), centravam-se nos seguintes pontos:

a) compressão do consumo supérfluo, principalmente de produtos importados, por meio do estabelecimento de tarifas elevadas e de restrições quantitativas às importações;

b) incentivo ao ingresso de capitais externos, principalmente na forma de empréstimos de governo a governo, a fim de aumentar os investimentos, sobretudo para a implantação da infra-estrutura básica;

c) realização de reforma agrária, para aumentar a oferta de alimentos e matériasprimas agrícolas, bem como a demanda de produtos industriais, mediante a expansão do mercado interno; e

d) maior participação do Estado na captação de recursos e na implantação de infraestruturas, como energia, transportes, comunicações, etc.

Ligada inicialmente à CEPAL, a denominada teoria da dependência, de interpretação tendencialmente mais próxima ao pensamento marxista, obteve grande êxito nas discussões sobre as causas do subdesenvolvimento. Como ressalta Souza (1999), destacaram-se nomes como André Frank, Theotônio dos Santos, Ruy Martini, F. H. Cardoso e Falleto. Em geral, esses autores sugeriam que a contradição do desenvolvimento não estaria nas relações entre centro e periferia, mas entre capital e trabalho. Fatores internos, oriundos das relações de produção e das disputas entre as classes sociais, que se apoderam do aparelho estatal, entravam ou favorecem o desenvolvimento. De acordo com Frank, citado por Bastos e Silva (1995), o subdesenvolvimento era resultado direto da drenagem de recursos para os países 
adiantados e da criação de estruturas econômicas destinadas a servir às necessidades da metrópole?.

Apesar de ter obtido grande repercussão junto à intelectualidade latino-americana, as teses defendidas pela CEPAL não ficaram imunes às críticas. Pelo contrário, tanto os liberais, como os marxistas, atacaram com vigor os prognósticos presentes no ideário cepalino. Se os liberais sempre viam nas propostas da CEPAL o risco de um socialismo burocrático, a ultraesquerda vislumbrava a suposta superficialidade dessa proposta, que mascarava a exploração social e econômica que mantinha a subordinação do trabalhador ao capital (Cardoso, 1993).

No entanto, como salienta Oliveira (1977), ao enfatizar os aspectos da dependência, os chamados teóricos do "modo de produção subdesenvolvido" quase sempre deixaram de tratar os fatores internos inerentes às formas de dominação que conformam as estruturas de acumulação próprias de cada país. Desse modo, ao incorporar a suposta dualidade existente nas chamadas sociedade moderna e sociedade tradicional, centrou-se em uma espécie de "beco sem saída rostowiano". No Brasil, a teoria do subdesenvolvimento sustentou as bases do desenvolvimentismo, desviando a atenção teórica e a ação política do problema da luta de classes que ocorria nesse período.

Assim, ainda de acordo com Oliveira (1977), toda a discussão que girava ao redor do pensamento da CEPAL, mesmo aquela advinda de seus mais ferrenhos adversários, ainda mantinha forte ligação com os próprios pressupostos da economia clássica, ou aquelas de filiação marginalista, neoclássica e Keynesiana. Apesar dos distintos caminhos ou entraves apresentados, em geral, o pensamento econômico prevalecente ainda assumia como principal meta o aumento no processo produtivo ou a ampliação na chamada renda nacional. Durante um longo período, igualou-se desenvolvimento a crescimento econômico. Os próprios medidores do desenvolvimento utilizados centravam-se em indicadores como o PIB e o PNB. Fortalecidas ao final do último século, novas propostas foram postas em cena, sobretudo aquelas que se afirmaram no seio das chamadas ciências sociais. Esse movimento teve uma importante repercussão na elaboração de novos indicadores alternativos. A própria

\footnotetext{
${ }^{9}$ No Brasil, outro autor que também obteve grande repercussão foi o economista Celso Furtado. Em seus trabalhos, Furtado defendeu a ampla participação do Estado na economia, dada por meio de investimentos em setores estratégicos, submetendo a política monetária e cambial aos próprios objetivos do desenvolvimento.

Cadernos do Leste

Artigos Cientificos

Belo Horizonte, Edição Especial, 2000 a 2008
} 
distinção entre os conceitos de crescimento e desenvolvimento talvez seja um dos principais indícios desse processo de redefinição.

\section{4- CRESCIMENTO OU DESENVOLVIMENTO ECONÔMICO? REVISÕES ÀS CRÍTICAS}

De acordo com Souza (1999), alguns dos primeiros enfoques econômicos que envolviam nomes como Meade e Solow, de tradição neoclássica e Harrod, Domar e Kaldor, de inspiração Keynesiana, consideravam o crescimento como sinônimo de desenvolvimento. As idéias expostas por Baldwin e Meier (1968) sintetizam a visão defendida pela tradição econômica predominante. Em geral, esses autores também acreditavam ser o desenvolvimento apenas outro nome dado ao processo de crescimento econômico. Apesar de reconhecer os distintos níveis de desenvolvimento, Meier e Baldwin também consideram a ausência de crescimento como o principal fator responsável pelo subdesenvolvimento. A existência de potenciais de capital, mão-de-obra e recursos naturais é, conforme esses autores, aspectos que determinam os diferentes estágios de desenvolvimento.

No entanto, pelo menos a partir de meados do século XX, um grupo relativamente grande de intelectuais já parecia reconhecer explicitamente as diferenças existentes entre crescimento e desenvolvimento econômico. Singer, utilizando-se de trechos das obras de alguns autores, esclarece:

"Podemos citar, nesse sentido, Barre 'a nosso ver o estudo do desenvolvimento não se confundirá com o estudo dos crescimentos equilibrados numa economia capitalista evoluída'; F. Perroux: 'A distinção entre crescimento e desenvolvimento parece agora aceita na literatura científica consagrada à dinâmica econômica (...) É intuitivo que o produto real global de uma nação ou de um outro conjunto social possa crescer sem que esta nação ou este conjunto se desenvolva'; E. Gannangé: 'A diferenciação(entre subdesenvolvimento e desenvolvimento insuficiente) indica uma diferença de natureza, ao acentuar que a economia subdesenvolvida recorre a outros mecanismos que a economia avançada""10. (Singer,1977, p. 38)

\footnotetext{
${ }^{10}$ Outros autores como Lewis, Hirshmam, Myrdal e Nurke, por exemplo, também destacaram-se ao propor novos aspectos e condicionantes inerentes ao desenvolvimento.

Cadernos do Leste

Artigos Cientificos

Belo Horizonte, Edição Especial, 2000 a 2008
} 
O próprio Singer também buscou frisar algumas das diferenças existentes entre esses dois conceitos. Para esse autor:

"Podemos definir crescimento econômico, em seu sentido mais amplo, como o aumento contínuo, no tempo, do Produto Nacional Bruto, em termos reais. Em seu sentido mais restrito, crescimento econômico seria o aumento do produto per capita no período considerado para análise. Desenvolvimento econômico, no sentido que se dá mais comumente a esta expressão, é um processo de transformação qualitativa da estrutura econômica de um país.” (Singer, 1977, p.38)

Assim, a noção de desenvolvimento na análise de Singer, como em boa parte dos grupos de estudiosos chamados genericamente de estruturalistas, implica em mudanças nas estruturas econômicas, sociais, políticas e institucionais ${ }^{11}$. Busca-se, nessa perspectiva, visualizar o desenvolvimento através da superação dos pontos de estrangulamento, fortalecendo a economia local pela ampliação dos mercados internos e aumento dos níveis de produtividade. As estruturas econômicas inadequadas prejudicavam o avanço tecnológico e o crescimento sistemático, o que poderia perpetuar as formas "pré-capitalistas" em determinados países e regiões.

Souza (1999) também parece confirmar a visão, já bastante difundida entre os economistas contemporâneos, que aponta nítidas diferenças entre crescimento e desenvolvimento econômico. Para esse autor, o crescimento econômico é visto como a expansão das bases materiais de produção, medida por exemplo pelo aumento da renda geral

da população. Já o desenvolvimento envolve aspectos que ultrapassam a dimensão restrita aos resultados do crescimento econômico, haja vista que os frutos da expansão não necessariamente beneficiam a economia como um todo e o conjunto de toda a população. Para Souza (1999, p. 21), a passagem do crescimento para o desenvolvimento econômico pode ser prejudicada pela existência de vários fatores, tais como:

\footnotetext{
${ }^{11}$ Para Furtado, por exemplo, há sensíveis diferenças entre crescimento e desenvolvimento. Para esse autor, “(...) o conceito de desenvolvimento compreende a idéia de crescimento, superando. Com efeito: ele se refere ao crescimento de um conjunto de estrutura complexa. Essa complexidade estrutural não é uma questão de nível tecnológico. Na verdade, ela traduz a diversidade das formas sociais e econômicas engendradas pela divisão do trabalho social.” (Furtado, 1983, p.90)
}

Cadernos do Leste Artigos Cientificos 
a) transferência de excedente de renda para outros países, reduzindo a capacidade de importar e de realizar investimentos;

b) apropriação de parcelas crescentes desse excedente para poucas pessoas no próprio país, aumentando a concentração da renda e da riqueza;

c) salários básicos extremamente baixos limitam o crescimento dos setores que produzem alimentos e outros bens de consumo mais popular;

d) empresas tradicionais não conseguem desenvolver-se pelo pouco dinamismo do setor de mercado interno;

e) dificuldades para implantação de atividades interligadas às empresas que mais crescem, exportadoras ou de mercado interno.

Nos últimos anos da década de 70, como mostra Haddad (1989), constatou-se em diversos países do mundo que a compatibilidade entre o crescimento econômico e o desenvolvimento social não ocorre de forma espontânea. A própria redução das desigualdades não foi atingida através dos impactos de uma economia eficiente. Assim,

“(...) o poder indutor do crescimento econômico propicia maior diferenciação dos sistemas sociais, sem, contudo, gerar mais eqüidade, pois esta não é impulsionada por nenhum mecanismo auto-sustentado, porquanto os efeitos genuínos do crescimento econômico estão estruturalmente vinculados aos imperativos da acumulação e à lógica da diferenciação social.” (Haddad, 1989, p.19)

O "nosso desenvolvimento", como salienta Haddad, deve ser programado para que as estruturas da economia reduzam as diferenças existentes entre as diversas regiões, entre as áreas urbanas e rurais. Ressalta-se, portanto, o papel fundamental do Estado, na medida em que se tornam quase inevitáveis os desequilíbrios distributivos em uma economia de livre mercado.

Dessa forma, apesar das diferenças existentes entre os conceitos de desenvolvimento, a antiga premissa de que os frutos do crescimento econômico seriam inevitavelmente incorporados a todos os estratos sociais passa a ser contestada não só por vários setores das chamadas ciências sociais, mas também por correntes da própria ciência econômica. Nesse Cadernos do Leste Artigos Científicos 
momento, pelo menos para uma parcela significativa da intelectualidade brasileira, parecia bastante claro que não havia uma ligação imediata entre o crescimento econômico e o desenvolvimento. Os novos aparatos teóricos e instrumentais metodológicos, que passaram a ser incorporados à tradição da análise econômica, confirmam o aparecimento de novas demandas. Ao enfatizar a necessidade de redefinições, Cardoso sugere:

"Evidentemente, numa revisão crítica dos valores herdados pelas sociedades contemporâneas, a idéia do progresso técnico e da racionalidade não é descartada, mas redefinida. O objetivo agora é o cálculo social dos custos e benefícios, e não a pseudo-racionalidade do mercado - que é na verdade a racionalidade da acumulação e da apropriação, por uns poucos, do resultado do trabalho da maioria. O alvo é a expansão do bem estar coletivo, não um aumento da produção." (Cardoso, 1993, p.164)

A discussão sobre tais questões suscitou uma série de controvérsias existentes entre as abordagens de desenvolvimento prevalecentes. A própria difusão de conceitos como qualidade de vida e condições de vida representa a tendência atual de ampliar a abrangência e o significado do termo desenvolvimento. Para Sliwiany (1997), alguns dos tradicionais indicadores econômicos, bastante utilizados, não respondem a algumas necessidades e especificidades nas análises socioeconômicas emergentes. Não podiam explicar boa parte das estruturas e tendências do desenvolvimento, mostrando-se incapazes de retratar as mudanças no nível de vida de uma determinada população.

A emersão da discussão ambiental, evidenciada já a partir dos finais da década de 60, foi um dos reflexos das incertezas e da falta de soluções realmente eficazes no combate aos problemas que atingiam boa parte das populações do mundo. Os limites ecológicos e os crescentes sintomas da exclusão social impuseram-se à incessante busca pelo crescimento econômico, várias vezes disfarçada nas várias teorias do desenvolvimento. A apresentação de novas alternativas parecia ser uma tendência inevitável. Os conceitos de eco desenvolvimento e de desenvolvimento sustentável representaram a insatisfação diante dos resultados presentes na promessa desenvolvimentista. 


\section{5- DO ECO DESENVOLVIMENTO AO DESENVOLVIMENTO SUSTENTÁVEL}

A partir de finais dos anos 60, as inúmeras questões ambientais passaram a ganhar significativa importância no debate internacional. Antes mesmo da Conferência de Estocolmo, realizada em 1972, outros aspectos associados à crescente degradação ambiental já haviam mobilizado a opinião pública em diversos países em todo o mundo. Vários movimentos sociais já questionavam a ordem estabelecida pela sociedade de consumo, sobretudo pelo novo ecologismo que surgiu com as agitações estudantis de 1968, que apresentavam como bandeiras de luta o antimilitarismo/pacifismo, os direitos das minorias, etc.

Por outro lado, vários estudos, como aqueles desenvolvidos por Carson, Boulding, Georgescu-Roegen, Ehlich \& Ehlich e Meadows, produzidos ao final da década de 60 e início de 70, já apontavam para alguns problemas específicos que atingiam o meio ambiente. Posteriormente, os trabalhos de Meadows e as considerações feitas pelo chamado Clube de Roma, também serviram como alerta às propostas políticas e aos modelos econômicos vigentes. Foi uma espécie de moratória imposta ao crescimento econômico, na tentativa de interromper a crescente disparidade entre as conseqüências ambientais do estilo de desenvolvimento industrial moderno e a capacidade de regeneração da biosfera.

De acordo com Brüseke (1998), a tese do "crescimento zero", defendida por Meadows, foi um ataque direto à promessa do desenvolvimento contínuo da sociedade industrial $^{12}$. Para esse autor, a descrença no crescimento ininterrupto da economia e dos padrões de consumo das populações, como afirmavam os analistas do Clube de Roma, foi o

12 Como mostra Brüseke (1998), as conclusões básicas dos pesquisadores envolvidos nos trabalhos publicados pelo Clube de Roma, sob coordenação de Meadows, foram:

- se as atuais tendências de crescimento da população mundial - industrialização, poluição, produção de alimentos e diminuição de recursos naturais - continuarem imutáveis, os limites de crescimento neste planeta serão alcançados algum dia dentro dos próximos cem anos. O resultado mais provável será um declínio súbito e incontrolável, tanto da população quanto da capacidade industrial.

- é possível modificar estas tendências de crescimento e formar uma condição de estabilidade ecológica e econômica que se possa manter até um futuro remoto. O estado de equilíbrio global poderá ser planejado de tal modo que as necessidades materiais básicas de cada pessoa na terra sejam satisfeitas, e que cada pessoa tenha igual oportunidade de realizar seu potencial humano individual. Se a população do mundo decidir empenhar-se em obter este segundo resultado, em vez de lutar pelo primeiro, quanto mais cedo ela começar a trabalhar para alcançá-lo, maiores serão suas possibilidades de êxito.

Cadernos do Leste

Artigos Cientificos

Belo Horizonte, Edição Especial, 2000 a 2008 
baluarte na luta contra a implementação generalizada das políticas pró-industrialização. Autores como Solow e Ul Haq também criticaram com vigor os prognósticos catastróficos do Clube de Roma. Para Ul Haq (1996), por exemplo, as diretrizes defendidas pelo Clube de Roma, por trás de um discurso aparentemente ecológico, impunham rígidos obstáculos ao desenvolvimento dos países pobres. No fundo, representaram uma forma de manter o status quo, cristalizando o abismo existente entre países desenvolvidos e não-desenvolvidos.

Foi em meio a esse debate que o canadense Maurice Strong, no início da década de 1970, utilizou inicialmente o conceito de ecodesenvolvimento, apresentando-o como uma concepção alternativa às políticas de desenvolvimento aplicadas até então (Brüseke, 1998). Partindo desse conceito, buscou-se caracterizar uma espécie de "idéia força", capaz de direcionar as iniciativas no sentido de dinamizar as economias sensíveis aos fenômenos de degradação do meio ambiente e de marginalidade social, cultural e política. O crescimento econômico e a emersão de formas ecologicamente sustentáveis dos recursos naturais e do espaço deveriam corporificar, diante das novas necessidades, dimensões plenamente integráveis (Viera, 1995).

Inacy Sachs foi outro autor de grande repercussão na análise referente às relações entre o meio ambiente e o desenvolvimento econômico. Esse autor, ao ratificar as idéias do chamado ecodesenvolvimento, passou a reforçar um estilo de desenvolvimento balizado em propostas e estratégias que sinalizam para formas alternativas de autogestão. Assim, como preconiza Sachs,

"O eco desenvolvimento é um estilo de desenvolvimento que, em cada ecorregião, insiste nas soluções específicas de seus problemas particulares, levando em conta os dados ecológicos da mesma forma que os culturais, as necessidades imediatas mas também aquelas a longo prazo. Opera, portanto, com critérios de progresso relativizados a cada caso, aí desempenhando papel importante a adaptação ao meio postulada pelos antropólogos. Sem negar a importância de intercâmbios, o eco desenvolvimento tenta reagir à moda predominante das soluções pretensamente universalistas e das fórmulas generalizadas. Em vez de atribuir um espaço excessivo à ajuda externa, dá um voto de confiança à capacidade das sociedades humanas de identificar os seus problemas e de lhes dar soluções originais, ainda que se inspirando em experiências alheias. Reagindo contra as transferências passivas e o espírito de imitação, põe em destaque a autoconfiança. Resistindo a um ecologismo exagerado,

Cadernos do Leste

Artigos Cientificos

Belo Horizonte, Edição Especial, 2000 a 2008 
sugere, ao contrário, a constante possibilidade de um esforço criador para o aproveitamento da margem de liberdade oferecida pelo meio, por maiores que sejam as restrições climáticas e naturais. As diversidades das culturas e das realizações humanas obtidas em meios naturais comparáveis são testemunhos eloquentes desta possibilidade. Mas o sucesso pressupõe o conhecimento do meio e a vontade de atingir um equilíbrio durável entre o homem e a natureza." (Sachs, 1986, p.18, In Matos et. al. 1999, p. 12)

Para Sachs, o chamado desenvolvimento endógeno deveria romper com a transposição mimética de modelos exógenos e de transferências de tecnologias. Assim, Sachs acredita que a chamada endogeneidade não deve ser compreendida como autarquia econômica. Ela conduz à autonomia no processo de definição do projeto nacional e tomada de decisões políticas ${ }^{13}$. Ainda de acordo com esse autor, o conceito de eco desenvolvimento ou autodesenvolvimento, deve ser tomado como um novo modelo de desenvolvimento, baseado na satisfação das necessidades básicas, na solidariedade com as gerações futuras, na participação da população, na preservação dos recursos naturais e do meio ambiente e na elaboração de um sistema social que assegure o emprego, a segurança social e o respeito às outras culturas e programas de educação. O problema das sociedades humanas não está, como enfatiza esse autor, na busca pelo desenvolvimento, mas nas propostas do que chamou de "mal desenvolvimento"

Em 1974, a Declaração de Cocoyoc, assim como o Relatório Que Faire, apresentado pela Fundação Dag Hammarskjöld, ao final de 1975, buscaram aprimorar algumas das propostas esboçadas inicialmente em outros trabalhos, como aqueles elaborados por Sachs. Nesses relatórios, fez-se novamente menção a "um outro desenvolvimento" - ou "desenvolvimento endógeno" - que agora deveria refletir conotações menos radicais e mais coerentes em relação a uma diretriz de experimentação politicamente cautelosa diante da nova ordem econômica internacional (Vieira, 1995).

\footnotetext{
${ }^{13}$ Sachs (1986, p.83-84) sugeria que o potencial de endogeneidade baseia-se em três elementos estreitamente ligados: "a capacidade cultural de pensar a si mesmo e de inovar, a capacidade político-administrativa de tomar decisões autônomas e de organizar a execução das mesmas, enfim, a capacidade do aparelho de produção para assegurar a sua reprodução, ampliada em conformidade com objetivos sociais de desenvolvimento."

${ }^{14}$ A problemática ambiental, na interpretação de Sachs, deveria ser encarada através dos princípios de solidariedade sincrônica (em relação às gerações atuais) e diacrônica (em relação às gerações futuras). Esses princípios de solidariedade foram posteriormente retomados, sob nova ótica, no próprio Relatório Brundtland.
}

Cadernos do Leste

Artigos Cientificos

Belo Horizonte, Edição Especial, 2000 a 2008 
Já em 1983, com a criação da Comissão Mundial sobre o Meio Ambiente e Desenvolvimento, e a consequente publicação do relatório Nosso Futuro Comum, em 1987, conhecido mundialmente como Relatório Brundtland, passou-se definitivamente a utilizar o conceito de desenvolvimento sustentável. Conforme esse mesmo relatório, ele passaria a ser definido como "aquele que atende às necessidades do presente sem comprometer a possibilidade de as gerações futuras atenderem as suas próprias necessidades”. A exploração dos recursos, a orientação dos investimentos e a mudança institucional deveriam agora se adequar às necessidades das gerações futuras e atuais. Nesse sentido, a sustentabilidade intergeracional afirmava-se como uma das condições essenciais do desenvolvimento.

Realizada em 1992 no Rio de Janeiro, a conferência da ONU, mundialmente conhecida como ECO 92, ao reunir algumas centenas de líderes internacionais, representou um grande debate sobre a temática ambiental. Publicada cinco anos depois do Relatório Brundtland, a Agenda 21, documento síntese das propostas elaboradas nesse encontro, destacou-se por absorver vários dos temas já tratados em 1987, tais como o consumo de energia e matérias primas, a conservação e utilização da biodiversidade e a proteção de ecossistemas frágeis, além de questões de cunho eminentemente socioeconômico ${ }^{15}$. Para Almeida Jr. (1994), a Agenda 21, popularizada como “estratégia da Cúpula da Terra para salvar nosso planeta”, foi por excelência o documento do desenvolvimento sustentável. Seu diagnóstico abrangente, seus programas e atividades, mas sobretudo a chancela internacional recebida, credenciam-na como uma firme resposta e uma referência mundial aos desafios e às propostas contidas na ideia de desenvolvimento sustentável. A Agenda 21, como sugere Almeida Jr., foi uma forma de resposta ao desafio de desenvolvimento sustentável, representado pela necessidade de elevar a qualidade de vida da população mundial, sem necessariamente exaurir os recursos naturais finitos.

Nesse momento, ao romper com o conflito existente entre os desenvolvimentistas e os ecologistas, o conceito de desenvolvimento sustentável logrou-se de uma suposta

\footnotetext{
15 Outro aspecto marcante desse encontro, como aponta Mota Silva (2000), refere-se à conquista de uma inegável e inovadora participação das Organizações Não-Governamentais (ONGs) e associações civis, que passaram a assumir um papel cada vez mais ativo no cenário político nacional e internacional. Assim, apesar de os resultados não terem correspondido às esperanças e às expectativas inicialmente depositadas, a ECO 92 mostrou-se bastante eficiente na difusão de uma consciência coletiva sobre a necessidade de participação política nas discussões sobre a problemática ambiental.
}

Cadernos do Leste Artigos Cientificos 
obviedade: a de desenvolver e preservar. No entanto, essa noção aparentemente coerente vem sendo alvo de pesadas críticas no debate acadêmico internacional. Para Leff,

"En ese momento empieza a caer en desuso el discurso del ecodesarrollo y a ser suplantado por el discurso del 'desarrollo sustenido'. Si bien muchos de los principios de ambos discursos son afines, las estrategias de poder del orden económica dominante han ido transformado el discurso ambiental crítico para somertelo a los dictados de la globalización económica.” (Leff, 1998, p. 18)

Leff acredita que a própria substituição da ideia de eco desenvolvimento pelo conceito desenvolvimento sustentável significava a adoção de uma postura de caráter mais reformista. $\mathrm{Na}$ verdade, o discurso da sustentabilidade (ponto central da ideia de desenvolvimento sustentável) assume um papel de legitimador dos próprios ideais do crescimento econômico, adaptando-o às novas condições ecológicas e sociais. As estratégias apresentadas, de acordo com esse mesmo autor, não propõem profundas mudanças nas estruturas de poder vigentes. Ao contrário, baseiam-se exatamente na reprodução dos atuais modelos de desenvolvimento, centrados em padrões econômicos que reproduzem as condições de desigualdade social e degradação ambiental.

Costa (1994) também ressalta alguns desses aspectos apontados por Leff. Conforme Costa, o desenvolvimento sustentável, ao desbancar as discussões acadêmicas e as formulações políticas dos desenvolvimentistas, oferece um discurso aparentemente conciliador, que vem sendo apresentado como uma tentativa de harmonizar desenvolvimento econômico com preservação ambiental. Para esse autor,

'Verdadeiro 'tour de force' na mediação do antagonismo entre os defensores do crescimento econômico a qualquer custo e os paladinos do preservacionismo, o desenvolvimento sustentável objetivou, ao incorporar a percepção tridimensional do desenvolvimento (vetores econômico, ecológico e social), estabelecer funcionalidade no que, até então, era dicotômico.” (Costa, 1994, p.47)

A emergência do desenvolvimento sustentável, ao romper com o determinismo da economia neoclássica e o radicalismo ecológico da chamada "revolução ambiental", como sugere Costa (1994, p.45), tornou-se uma inevitável panacéia da "sabedoria convencional”. Há Cadernos do Leste Artigos Cientificos 
aqueles que “o consideram o 'símbolo de um consenso ideal' ou, ao arrepio das idéias de Kuhn, o "novo paradigma do desenvolvimento"'.

Todavia, de acordo com Guimarães (1993), até o presente momento, não há grandes avanços na busca por soluções definitivas, tampouco inovadoras, para o equacionamento dos chamados "problemas ambientais" ". Apesar de ter havido significativos esforços na tentativa de implementação das chamadas políticas de desenvolvimento sustentável, poucos foram os resultados efetivos. Para Guimarães,

“Até o momento, o que se vê são transformações somente cosméticas, que tendem a 'esverdecer' o estilo atual, sem de fato propiciar as mudanças com as quais os governos representados no Rio haviam proposto.” (Guimarães, 1993, p. 118)

Em geral, as políticas ambientais ainda são bem restritas e específicas. Predominam medidas bem paliativas: um decreto aqui, uma legislação acolá. Não atingem o problema em sua essência: deixam de lado os conflitos e as contradições presentes na sociedade moderna ${ }^{17}$. Em vários momentos, desafios de natureza eminentemente políticas são relevados, acobertados por pseudo-soluções técnicas ou por soluções aparentemente consensuais. Para Ul Haq (1996), o debate ambiental e a elaboração de políticas ambientais realmente eficientes devem superar interpretações unidimensionais, às vezes ainda presas a aspectos econômicos ou fechadas em posturas radicalmente preservacionistas. Para esse autor,

"The environmental debate must be given a human perspective to save it from the excesses of environmental fanatics, who often seem more interested in saving trees than in saving people. A more meaningful concept, therefore, is sustainable development, putting people at the center of the environmental debate." (Ul Haq, 1996, p.78)

\footnotetext{
${ }^{16}$ A própria Agenda 21, conforme Almeida Jr. (1994), é ainda um documento bastante tímido e indefinido quanto aos mecanismos de responsabilidade, sobretudo no tocante ao financiamento e à implementação dos projetos de desenvolvimento sustentável. Muitas discussões, como aquelas referentes aos ditos problemas ambientais globais, esbarraram em inúmeros interesses políticos e econômicos internacionais, criando inúmeros impasses e dificuldades para o estabelecimento de alternativas realmente eficientes.

${ }^{17}$ Mesmo no campo conceitual, como indica Costa, "falta-lhe precisão e conteúdo, cabendo as mais variadas definições" (Costa, 1998, p.1736). Costa (1994, p.55) também chama atenção para esse aspecto: "O conceito de desenvolvimento sustentável consiste ainda, numa proposição meramente normativa, mas nunca num marco teórico referencial, por excelência, da formulação de estratégias e políticas de desenvolvimento, como chegam a advogar alguns entusiastas".

Cadernos do Leste
}

Artigos Cientificos

Belo Horizonte, Edição Especial, 2000 a 2008 
Há na análise de Ul Haq uma relação intrínseca entre as dimensões ambiental e humana. O desenvolvimento sustentável requer mais do que a preservação ambiental. As vidas humanas devem necessariamente ser revalorizadas, tanto nas formas como hoje se realizam como em suas possibilidades futuras. Ainda de acordo com esse autor, o homem e o ambiente devem ser vistos através da ampliação de suas potencialidades, atreladas ao presente e ao futuro.

\section{6- DESENVOLVIMENTO HUMANO; DEFINIÇÕES E APLICAÇÕES}

A última década do século passado representa um importante momento nas discussões acerca do desenvolvimento. Lançado em 24 de maio de 1990, pelo Programa das Nações Unidas sobre o Desenvolvimento (PNUD), os diversos Relatórios do Desenvolvimento Humano divulgaram novas bases de interpretação e novos instrumentos para a mensuração da qualidade de vida das populações. No Brasil, esses relatórios passaram a ser regularmente publicados só a partir de 1996, quando tornaram-se instrumentos de grande utilização no meio acadêmico e foram bastante difundidos pela mídia. Esses trabalhos, produzidos por diversas instituições e organismos internacionais, ao ratificarem a noção de desenvolvimento humano, empregadas inicialmente por autores como Amartya Sen e Mahbud Ul Haq, buscam integrar outras dimensões que vão além dos tradicionais indicadores do crescimento econômico. De acordo com um desses relatórios, publicado pelo PNUD,

“O crescimento econômico é uma condição tão necessária para o desenvolvimento humano como este é para o crescimento econômico. Mas não é uma condição suficiente: a vinculação entre os dois não é automática." (...) “O conceito do desenvolvimento humano destaca os fins do desenvolvimento e do progresso, ao invés dos meios. O desenvolvimento humano engloba tanto o processo de alargamento das escolhas pessoais quanto o nível de bem-estar alcançado. O objetivo do desenvolvimento deve ser a criação de um ambiente propício para as pessoas terem uma vida longa, saudável e criativa. Apesar de parecer uma verdade pura e simples, tal premissa é esquecida quando se leva em conta apenas a acumulação de bens e riqueza." (RDH, 1998, p. 36 e 102) 
A inovação obtida no conceito de desenvolvimento humano, como frisou Santos (1996), reside exatamente no alargamento conceitual obtido pelo rompimento da visão que restringe o desenvolvimento a resultados meramente econômicos ou pela quantidade de capital acumulado pelo país. Nesse sentido, o desenvolvimento humano relaciona-se à garantia do equilíbrio sustentável entre o crescimento econômico e o fortalecimento da capacidade de as pessoas beneficiarem-se dele. Não se trata de considerar o crescimento econômico como antítese do desenvolvimento humano, mas sim como condição insuficiente. A vinculação entre ambos não é imediata.

$\mathrm{Na}$ verdade, como indica Ul Haq (1996), essas redefinições aparentemente novas, retomam antigas discussões presentes nos trabalhos de clássicos como Einstein e Keynes e, até mesmo, Aristóteles. Para esse autor (1996, p.3), "We are rediscovering the obvious - that people are both the means and the end of economic development”. Para esse autor:

"The basic purpose of development is to enlarge people's choice. In principle, these choices can be infinite and can change over time. People often value achievements that do not show up at all, or not immediately, in income on growth figures: greater access to knowledge, better nutrition and health services, more secure livelihoods, security against crime and physical violence, satisfying leisure hours, political and cultural freedoms and a sense of participation in community activities. The objective of development is to create an enabling environment for people to enjoy long, healthy and creative lives." (Ul Haq, 1996, p.14)

A diferença básica entre o crescimento econômico e o desenvolvimento humano é que o primeiro focaliza exclusivamente a expansão de apenas uma escolha, a renda, enquanto o segundo enfatiza o alargamento de todas as escolhas humanas, que vão além do que vem sendo usualmente chamado de bem estar econômico. O uso que as pessoas fazem da riqueza e não ela em si, é decisivo. Ainda de acordo com esse autor,

"The human development paradigm consistently takes the view that growth is not the end of economic development - but that the absence of growth often is. Economic growth is essential for human development, but to fully exploit the opportunities for improved well-being that growth offers, it needs to be properly managed." (Ul Haq, 1996, p.14) 
A distribuição de renda é, como demonstra Ul Haq, um importante fator que impede as pessoas de beneficiarem-se do crescimento econômico. Nesses casos, um conjunto relativamente expressivo de indivíduos ou grupos sociais pode ficar à margem do progresso material obtido, aumentando a parcela dos chamados excluídos. Nesses casos, surge a necessidade de intervenção do poder público, a fim de minimizar os efeitos da concentração de renda.

Amartya Sen vem sendo atualmente outro autor muito citado no debate sobre o desenvolvimento. Natural da Índia, Sen vem investindo em uma estrutura conceitual e filosófica intrínseca a essa temática. Esse autor faz pesadas críticas à tradicional "economia do bem estar”, que ora enfatiza a posse de bens ou mercadorias, ora a própria noção de utilidade. Para Sen, uma concepção de bem-estar que focaliza bens e mercadorias ao invés de pessoas inevitavelmente negligencia a chamada “conversão variável”, ou seja, o que cada um, de modo particular, pode fazer com tais bens e mercadorias. Os bens são necessários, mas a avaliação sobre a qualidade de vida da população deve recair sobre o fim que esses bens proporcionam: a conversão de bens em efetivações humanas. Para Sen, (1993A, p. 324), "os bens primários são meios para as liberdades, ao passo que as capacidades de realização são expressões das próprias liberdades." Ainda de acordo com esse autor,

“O bem-estar de uma pessoa não é realmente uma questão de quão rica ela é (...) A posse de mercadorias é um meio para o fim que é o bem-estar, mas essa posse dificilmente pode ser o próprio fim." (Sen, In: Crocker, 1993B, p. 107)

Sen acredita que o desenvolvimento deve ter como objetivo último a melhoria dos "tipos de vida" que os seres humanos estão vivendo. Tanto em teoria quanto na prática o desenvolvimento deve ser definido em relação àquilo que os seres humanos podem fazer ou ser. Esse autor sugere:

"Os seres humanos são agentes, beneficiários e juizes do progresso, mas também são, direta ou indiretamente, os meios primários de toda a produção. Esse duplo papel dos seres humanos dá origem à confusão entre fins e meios no planejamento e na elaboração de políticas. De fato, essa confusão pode tomar - e frequentemente toma

- a forma de uma noção da produção e da prosperidade como a essência do Cadernos do Leste 
progresso, considerando as pessoas como os meios pelos quais tal progresso na produção é obtido (ao invés de considerar a vida das pessoas como a finalidade última e tratar a produção e a prosperidade como meios, tão somente, para atingi-la)." (Sen, 1993A, p.313)

O problema não está, como aponta o próprio Sen, na busca pela prosperidade e pelo consumo, mas em considerá-los objetivos últimos do planejamento e das políticas públicas. Sen propõe um novo desenvolvimento, sendo redefinido como desenvolvimento humano: relativo à formação, expansão e utilização das possibilidades humanas, através da promoção de determinadas efetividades e da expansão das capacidades de realização das formas de existência e de atividade ${ }^{18}$. Os problemas relativos à fome e à pobreza no mundo, conforme Sen, indicam deficiências tanto técnicas e políticas, quanto conceituais e éticas. A ética do desenvolvimento precisa ser elaborada em relação dialética com a investigação empírica sobre os fatores que impedem o (bom) desenvolvimento, assim como o que produz a pobreza, a carência de alimentos, a fome endêmica, dentre outros. Para Sen, as ciências sociais precisam freqüentemente recorrer à ética para esclarecer o que devemos entender por "privação humana", "bem-estar", "qualidade de vida" e "desenvolvimento"19.

\section{7- O DESENVOLVIMENTO HUMANO E A SUSTENTABILIDADE AMBIENTAL}

Recentemente, vários esforços vêm sendo empreendidos com o objetivo de integrar alguns pressupostos do desenvolvimento humano à crescente necessidade de preservação

\footnotetext{
${ }^{18}$ Sen utiliza o termo efetivações para designar os diferentes estados do ser humano e de suas atividades, refletindo uma parte de suas potencialidades. Trata-se, portanto, de uma conquista de uma pessoa: é o que ela consegue fazer ou ser e qualquer dessas efetivações reflete uma parte do estado dessa pessoa. Há efetivações elementares como evitar a morbidade precoce, alimentar-se adequadamente, realizar os movimentos usuais, até efetivações mais complexas, tais como: desenvolver o auto-respeito, tomar parte da vida em comunidade e apresentar-se em público sem envergonhar-se. Já o conceito de capacidade refere-se ao grau de potencialidade de realização humana. Se se considera que a vida oferece um certo número de possibilidades, efetiváveis ou não, a capacidade humana reflete a liberdade individual de escolher entre vários modos de viver. Assim, a capacidade é uma noção derivada. Ela reflete as várias combinações de efetivações (atividades e modos de ser) que uma pessoa pode alcançar.

${ }^{19}$ Em seu trabalho "Sobre Ética e Economia", publicado no Brasil em 1999, Sen chama a atenção para o distanciamento da análise econômica em relação às questões eminentemente éticas. Sen argumenta que o comportamento real dos seres humanos é diretamente afetado por considerações éticas, que influenciam decisivamente a conduta humana. A suposição extremamente restrita do comportamento auto-interessado, predominante na teoria econômica prevalecente, vem impedindo a compreensão de relações significativas.
}

Cadernos do Leste

Artigos Cientificos

Belo Horizonte, Edição Especial, 2000 a 2008 
ambiental, haja vista o fortalecimento do debate em torno dos aspectos ligados à idéia de sustentabilidade. Nessa última metade do século XX, novas discussões retomam o grande desafio que atualmente se impõe à humanidade: o de estabelecer uma nova relação entre o homem e a natureza, além da própria relação homem/homem. Para Silva,

"É o conceito de desenvolvimento que deve mudar para colocar em seu centro o que é o mais importante, o homem em suas dimensões, que dão substância ao presente e ao futuro da humanidade: o social e o ecológico. (...) O que é correto, não obstante, é colocar o homem, com todas as suas possibilidades, no centro da questão, o homem capaz de edificar seu presente e seu futuro: esse é o nosso referencial." (Silva, 1998, p.549)

Essa noção prospectiva passa a estar quase sempre presente nas atuais propostas contidas no discurso do desenvolvimento. A intensificação dos movimentos ambientalistas força a incorporação de uma nova perspectiva nas propostas do desenvolvimento humano: a preservação da vida na Terra. Inúmeras organizações internacionais, não governamentais ou supranacionais, como a ONU por exemplo, não só incorporaram noção de sustentabilidade em suas diretrizes políticas, mas empreendem um grande esforço na difusão de seus princípios. De acordo com o RDH (1998),

“A sustentabilidade é outro aspecto fundamental da noção de desenvolvimento humano. Ela é definida no paradigma como a expansão das escolhas e das oportunidades da geração presente, mas sem desconsiderar aquelas das gerações futuras. A equidade entre gerações está no centro do desenvolvimento humano sustentável. E a sustentabilidade implica algo que não é relacionado apenas ao meio ambiente, mas abrange também aspectos institucionais, culturais, sociais e políticos." (RDH, 1998, p. 37)

A inclusão da perspectiva da sustentabilidade aos princípios do Desenvolvimento Humano vem criando novos conceitos, como o chamado Desenvolvimento Humano Sustentável. Conforme interpretação de Ul Haq, essa idéia envolve os seguintes componentes básicos:

- eqüidade (igualdade de oportunidade para todas as pessoas na sociedade); Cadernos do Leste Artigos Científicos 
- caráter sustentável (de tais oportunidades de uma geração para a próxima);

- produtividade e “empoderamento" (de pessoas de modo que elas participem - e se beneficiem - do processo de desenvolvimento).

Ainda de acordo com Ul Haq (1996), a sustentabilidade deve ser vista como um dos componentes essenciais no paradigma do desenvolvimento humano. $O$ conceito de desenvolvimento humano sustentável, ao assumir o homem como foco central, busca ampliar a abrangência necessária ao debate ambiental. Para esse autor,

"Development opportunities and human choices must be preserved for future generations - not each and every form of natural capital or every ecological resource or every species. If more efficient substitutes are available, they must be used, as they have been throughout history. What must be sustained for the next generation is the capacity to enjoy at lest the level of well-being that our own generation enjoys." (U1 Haq, 1996, p. 79)

A preservação ambiental, como mostra o próprio Ul Haq, é apenas um dos objetivos do desenvolvimento. A ampliação das oportunidades humanas passa pela superação de alguns débitos que vão além da chamada "problemática ambiental". Nesse sentido, a sustentabilidade do desenvolvimento refere-se não apenas às perspectivas futuras, mas sobretudo às necessidades do presente. Redistribuição de renda, justiça social, democracia e preservação ambiental são dimensões do desenvolvimento humano, sustentáveis no futuro, mas fundamentadas essencialmente no presente.

\section{8- FORMAS DE ARTICULAÇÃO ENTRE OS INDICADORES DE CRESCIMENTO ECONÔMICO E DESENVOLVIMENTO HUMANO; EXEMPLOS E A ANÁLISE DE SEN}

Pelo menos a partir de meados do século passado, inúmeros autores já apontavam as diferenças existentes entre as definições de crescimento econômico e desenvolvimento. No entanto, ainda persistem nítidas controvérsias em relação aos caminhos necessários e os possíveis condicionantes para se atingir o desenvolvimento. Vários são os receituários e Cadernos do Leste Artigos Cientificos 
prognósticos apontados. Em geral, apesar de não considerá-lo como condição suficiente, o crescimento econômico vem sendo tomado por vários autores como necessário para que ocorra o processo de desenvolvimento. Funcionaria como uma espécie de pré-requisito à melhoria das condições de vida das populações. As próprias idéias defendidas por Singer (1977), um dos críticos da teoria clássica, ainda reforçam essa premissa. De acordo com esse autor,

"É obvio que o desenvolvimento constitui um caso particular do crescimento econômico. É, em termos, o crescimento econômico que se verifica em circunstâncias históricas bem determinadas, pois trata-se do aumento do PNB real (total ou per capita) devido à passagem da economia de uma situação de subdesenvolvimento (ou pré-industrial) para outra, que poderíamos chamar de industrial ou desenvolvida." (Singer, 1977. p. 38)

Mais recentemente, outros autores também reafirmaram essa dependência implícita em relação ao crescimento econômico, mesmo quando envolve especificamente o conceito de desenvolvimento sustentável ${ }^{20}$. Em uma das passagens de seu trabalho, Costa parece ser bastante enfático,

"A propósito, é oportuno frisar que, embora o crescimento seja condição 'sine quanon’, mas não suficiente, do desenvolvimento, este só irrompe necessariamente precedido daquele. A mesma ligação também é válida para o desenvolvimento sustentável." (Costa, 1994. p.51)

Ao averiguar o caso específico dos países chamados de economia emergente, esse autor reafirma a dependência implícita em relação ao investimentos produtivos e de infraestrutura de longo prazo, que depende em grande medida da expansão econômica.

\footnotetext{
${ }^{20}$ O próprio Sachs, autor cujas críticas tiveram grande repercussão, em certa medida também reafirma essa condição inerente ao desenvolvimento, entendido como ecodesenvolvimento, endodesenvolvimento, etc. Para esse autor, é "comum a todos o reconhecimento de que o desenvolvimento não pode ser traduzido tão-somente ao crescimento expresso em termos puramente quantitativos; de que, na melhor das hipóteses, o crescimento é uma condição necessária, mas de forma alguma suficiente, do desenvolvimento; de que o crescimento pode subentender processos cujas recaídas sociais estão longe de ser unívocas e das quais a análise quantitativa convencional não consegue, por si só, dar conta." (Sachs, 1986, p.75)
}

Cadernos do Leste

Artigos Cientificos 
Do contrário, restará o cenário de estagnação econômica, que perpetuará o atraso, a dependência e todas as seqüelas, inclusive aquelas ligadas aos aspectos ambientais.

Para Ul Haq (1996), o "paradigma" do desenvolvimento humano prestou um importante serviço para o questionamento da ligação automática entre o crescimento econômico e a ampliação das escolhas humanas. Essa ligação depende muito mais da distribuição igualitária dos frutos desse crescimento do que de sua quantidade. O enriquecimento da vida das pessoas depende, em grande medida, de uma ação pública deliberada, através de investimentos nos serviços de saúde e educação. Ao enumerar determinados condicionantes, caminhos ou descaminhos rumo ao desenvolvimento humano, orientados para uma ação pública deliberada, reafirma-se a própria proeminência das variáveis econômicas. A necessidade da existência de um conjunto de fatores, em boa medida, confirma o próprio crescimento econômico como ponto de partida. Mesmo sendo um dos proponentes das idéias do desenvolvimento humano, em determinados momentos, esse autor ainda ressalta essa necessidade,

"But we must be careful. Rejecting an automatic link between income expansion and flourishing human lives is not rejecting growth itself. Economic growth is essential in poor societies for reducing or eliminating poverty. But the quality of this growth is just as important as its quantity. Conscious public is needed to translate economic growth into people’s lives." (Ul Haq, 1996, p.15).

Apesar de apresentar uma postura mais prudente do que aquela que imperava na tradição econômica, chamando atenção para alguns aspectos complementares, Ul Haq reforça a necessidade de crescimento econômico, pelo menos para a eliminação da pobreza nos países mais pobres. O caminho que leva ao desenvolvimento humano pode ou não ser concluído, dependendo dos acertos ou equívocos cometidos no percurso. A implementação de ações públicas deliberadas, mantidas, por exemplo, através de um sistema de impostos progressivos, de um programa de crédito bancário direcionado ao atendimento das populações mais pobres e de uma maior abrangência dos serviços sociais básicos, poderia funcionar como uma ponte entre crescimento e desenvolvimento (Ul Haq, 1996). 
Mais recentemente, Ramires et. al. (2000), no trabalho Economic Growth e Human Development, sugerem que os distintos níveis do Produto Interno Bruto (PIB) per capita podem levar a diferentes performances no desenvolvimento humano, conforme a alocação dos recursos disponíveis, a atuação das instituições e as variações no ambiente. Por um lado, a distribuição da renda, o combate à pobreza, a contenção dos gastos e a ampliação da renda familiar e por outro a ação governamental, ampliando os investimentos nas áreas de saúde e educação, são aspectos que influenciam decisivamente na passagem entre o crescimento econômico e o desenvolvimento humano.

Mesmo sugerindo novos pontos à análise social, Ramirez et. al. (2000) ainda confirmam a expansão do potencial econômico, medido através do PIB, como ponto obrigatório ao processo de desenvolvimento humano. As próprias dimensões ambiental e humana são vistas como formas de acumulação de capital, ora representadas pelo estoque de capital físico, ora pelo chamado capital social ${ }^{21}$.

Embora sejam distintas, as várias concepções acerca do processo de desenvolvimento parecem confirmar a ampliação das bases produtivas e consequentemente das rendas nacionais, como pré-requisito fundamental ao desenvolvimento. Assim, apesar de cumprirem um importante papel ao diferenciar crescimento econômico de desenvolvimento, essas abordagens ainda merecem ser revisadas. As inter-relações entre as diversas dimensões que compõem a realidade social ultrapassam esse espectro analítico.

A compreensão dos encadeamentos que envolvem o processo de desenvolvimento é fundamental para a construção de novas alternativas que não esbarrem em alguns equívocos cometidos no passado.

\footnotetext{
${ }^{21}$ Uma importante distinção sobre esse aspecto é feita por Sen (2000). Em geral, como mostra esse autor, a literatura econômica contemporânea vem usando a idéia de capital social, derivada na noção de capital humano, para designar as potencialidades humanas para aumentar as possibilidades de produção. Por exemplo, se a educação torna a pessoa mais eficiente na produção de mercadoria, haja vista sua melhor capacidade de ler, comunicar-se, argumentar, etc, seus benefícios podem ser considerados como ganhos em termos de capital social. Já a perspectiva da capacidade humana concentra-se no potencial (liberdade substantiva) das pessoas para levar a vida que têm razão em valorizar e para melhorar as escolhas reais que elas possuem. Há, portanto, uma diferença valorativa crucial entre o enfoque do capital humano e o das capacidades humanas. Na primeira perspectiva, o foco é centrado nas possibilidades humanas de reproduzir e ampliar capital, através de seu desempenho econômico. No segundo enfoque a expansão das liberdades humanas é tida não apenas como meio para o desenvolvimento, mais um fim em si mesma .
}

Cadernos do Leste

Artigos Científicos

Belo Horizonte, Edição Especial, 2000 a 2008 


\section{9- A ANÁLISE DE SEN; AS INTER-RELAÇÕES ENTRE AS LIBERDADES CONSTITUTIVAS E INSTRUMENTAIS}

Em um de seus mais recentes trabalhos, Desenvolvimento como Liberdade, publicado no Brasil em 2000, Sen apresenta interpretações distintas acerca das possíveis relações entre o crescimento econômico e o desenvolvimento humano. Em sua análise, esse autor considera que o desenvolvimento consiste na eliminação das diversas privações à liberdade humana, que limitam as escolhas e as oportunidades de as pessoas exercerem satisfatoriamente sua condição de agente ${ }^{22}$. Para Sen a expansão dessas liberdades tanto pode ser considerada como o fim primordial, como principal meio do desenvolvimento, representados pelos papéis constitutivo e instrumental da liberdade. O papel constitutivo relaciona-se à importância substantiva da liberdade ao enriquecimento da vida humana. Refere-se, portanto, à valorização inerente das próprias escolhas disponíveis. Isso envolve, por exemplo, as possibilidades de se evitar privações como a fome, a morbidade evitável, o analfabetismo e a coação política ${ }^{23}$. A importância intrínseca da liberdade, evidenciada como fim do desenvolvimento, também deve estar associada à eficácia instrumental da liberdade. Esse papel instrumental refere-se ao modo como os diferentes tipos de direitos,

\footnotetext{
${ }^{22}$ A expressão "condição de agente" às vezes é empregada na literatura sobre economia e teoria dos jogos em referência a uma pessoa que está agindo em nome de outra e cujas realizações devem ser avaliadas à luz dos objetivos da outra pessoa. Sen utiliza o termo agente em seu significado mais antigo, de alguém que age e ocasiona mudança e cujas realizações podem ser julgadas de acordo com seus próprios valores e objetivos.

${ }^{23}$ Para Sen, o conjunto de capacidades representa a liberdade pessoal de realizar várias combinações de efetivações. Se a liberdade é intrinsecamente relevante, as combinações disponíveis para a escol ha são todas importantes para se avaliar o que é vantajoso para uma pessoa, mesmo que se escolha apenas uma alternativa. Nessa perspectiva, a escolha é, em si mesma, uma característica valiosa da vida de uma pessoa. Por exemplo, um aumento da longevidade é geralmente tido como uma melhoria na qualidade de vida. Em parte isso ocorre também porque outras realizações, tais como evitar doenças, tendem a acompanhar a longevidade. Mas uma longevidade maior também pode ser vista como um aumento da liberdade de viver mais tempo. Frequientemente damos isso por aceito como base no raciocínio sólido de que, havendo opção, as pessoas valorizam viver mais tempo; nesse sentido, a realização observada de uma vida prolongada reflete uma liberdade maior do que a que se desfrutou (Sen, 1993A).
}

Cadernos do Leste

Artigos Cientificos

Belo Horizonte, Edição Especial, 2000 a 2008 


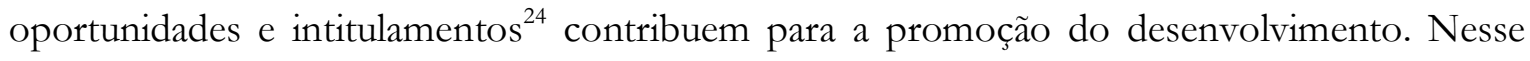
sentido, a liberdade torna-se um importante instrumento para as pessoas alcançarem as diversas alternativas consideradas como valiosas, incluídas dentro de um conjunto maior de opções.

Sen destaca cinco tipos básicos de liberdades instrumentais: liberdades políticas, facilidades econômicas, oportunidades sociais, garantias de transparência e segurança protetora. As liberdades políticas, incluindo os direitos civis, referem-se, dentre outras coisas, às oportunidades que as pessoas têm para determinar seu governante e com base em que princípios, além de incluírem as possibilidades de fiscalizar e criticar as autoridades, através da liberdade de expressão política e de imprensa, além dos direitos políticos associados à democracia (considerada em seu sentido mais abrangente). As chamadas facilidades econômicas estão ligadas às oportunidades de os indivíduos utilizarem-se dos recursos econômicos com propósitos de consumo, produção ou troca. Isso depende fundamentalmente do capital disponível, das condições de troca e do funcionamento do mercado. Já as oportunidades sociais vinculam-se às disposições que a sociedade estabelece nas áreas de educação, saúde, segurança, etc. Essas facilidades são importantes não só para a condução da vida privada, mas também para uma participação mais efetiva em atividades econômicas e políticas. As garantias de transparência referem-se à necessidade de um determinado nível de sinceridade nas interações sociais: a liberdade de lidar uns com os outros sob mínimas garantias de dessegredo e clareza. Essas garantias têm, por exemplo, um papel fundamental como inibidores da corrupção, da irresponsabilidade financeira e de transações ilícitas. Por último, a segurança protetora relaciona-se à capacidade de garantir uma rede de segurança social, impedindo que parte da população afetada seja reduzida à miséria abjeta e à fome coletiva.

\footnotetext{
${ }^{24}$ A palavra intitulamento, conforme tradução de MOTA, L. T., origina-se do verbo latino intitulare. O termo inglês Entitlement foi empregado por Sen, em seu trabalho em co-autoria com Jean Drèze, Hunger and public action (1989), para representar “(...) o conjunto de pacotes alternativos de bens que podem ser adquiridos mediante o uso dos vários canais legais de aquisição facultados a essa pessoa. Em uma economia de mercado com propriedade privada, o conjunto do entitlement de uma pessoa é determinado pelo pacote original de bens que ela possui (denominado 'dotação') e pelos vários pacotes alternativos que ela adquirir, começando com cada dotação inicial, por meio de comércio e produção. Uma pessoa passa fome quando seu entitlement não inclui, no conjunto [que é formado pelo pacotes alternativos de bens que ela pode adquirir] nenhum pacote de bens que contenha uma quantidade de alimentos."
}

Cadernos do Leste

Artigos Cientificos

Belo Horizonte, Edição Especial, 2000 a 2008 
Algumas medidas, como os benefícios para os desempregados, a distribuição de alimentos em momentos de crise ou a criação de empregos públicos em uma situação de emergência podem impedir que um grupo de pessoas sucumba diante de privações materiais básicas.

Em geral, como sugere Sen, na análise do desenvolvimento, a importância intrínseca da liberdade humana é geralmente suplementada pela eficácia instrumental das liberdades específicas na promoção de liberdades de outros tipos. Os encadeamentos entre as diferentes formas de liberdade devem ser considerados como empíricos e causais e não constitutivos e/ou compositivos. Para esse autor, o essencial não está na constatação óbvia da influência de cada uma dessas liberdades na promoção do desenvolvimento, uma vez que ele próprio pode ser visto como um processo de ampliação das liberdades humanas. De acordo com Sen,

"A eficácia da liberdade como instrumento reside no fato de que diferentes tipos de liberdade apresentam inter-relações entre si, e um tipo de liberdade pode contribuir imensamente para promover liberdades de outros tipos." (Sen, 2000, p.54)

Transformações em determinados tipos de liberdade podem, direta ou indiretamente, trazer significativas repercussões em outras. $O$ fato de o crescimento nas chamadas facilidades econômicas ajudar não só elevando rendas privadas, mas também permitindo ao Estado financiar a seguridade social através de uma ativa intervenção governamental, já vem atualmente sendo amplamente aceito. No entanto, outros tipos de relações ainda são pouco compreendidos e explorados. Por exemplo a expansão e o acesso aos serviços sociais básicos, independente do crescimento na riqueza ou nas rendas, pode ser fundamental à ampliação de outros tipos de liberdade, como viver mais tempo e com melhor qualidade. O próprio sistema educacional e os serviços de saúde também são produtivos para o aumento do processo de crescimento econômico. Há, portanto, um conjunto imbricado de correlações entre as várias dimensões da realidade social, que ultrapassa uma simples relação de mão única: do crescimento econômico. 
Ao investigar as variações no desenvolvimento verificadas em algumas regiões do mundo, conforme distintos níveis de crescimento econômico, Sen (2000, p.63) destacou dois tipos centrais de contradições:

1) para economias de crescimento econômico elevado, o contraste entre:

1.1) as com grande êxito no aumento da duração e qualidade de vida (como Coréia do Sul e Taiwan) e

1.2) as sem um êxito comparável nesses outros campos (como o Brasil).

2) para economias com grande êxito no aumento da duração e qualidade de vida, o contraste entre:

2.1) as com grande êxito em termos de elevado crescimento econômico (como Coréia do Sul e Taiwan) e

2.2) as sem muito êxito em termos de elevado crescimento econômico (como Sri Lanka, China pré-reforma, o Estado indiano do Kerala).

Assim, conforme os exemplos mencionados por Sen, a obtenção de expressivos resultados em termos de melhorias nas condições de vida das populações pode ocorrer mediante dois processos: os "mediados pelo crescimento" e aqueles "conduzidos pelo custeio público". O primeiro vincula-se a um rápido crescimento econômico e seu êxito depende de uma base ampla e economicamente abrangente e da utilização da maior prosperidade econômica na expansão de serviços sociais relevantes. Logo, o principal impacto do crescimento econômico depende do modo como seus frutos são aproveitados e investidos em ganhos relativos à própria população. Diferente do que ocorre no primeiro caso, o processo conduzido pelo custeio público não opera por meio de um rápido crescimento econômico, e sim por meio de um hábil e eficiente sistema de manutenção social nos serviços de saúde, educação e em outras disposições sociais relevantes. Os investimentos nesses setores, além dos resultados diretos, retornam sob forma de ganhos em outros setores, como no próprio crescimento das facilidades econômicas. 
Para Sen, as experiências observadas nas economias de países como o Sri Lanka, a China pré-reforma, a Costa Rica ou o estado do Kerala na Índia, que apresentaram reduções muito rápidas nas taxas de mortalidade e melhoras na qualidade de vida sem grande crescimento econômico, são exemplos claros desse processo. Os habitantes do Kerala, China ou Sri Lanka, mesmo com baixo PNB per capita, apresentam níveis de expectativa de vida bem mais elevados do que as populações do Gabão, Brasil, África do Sul e Namíbia ${ }^{25}$. No caso específico de Gabão os resultados são ainda mais contundentes. Mesmo apresentando o maior PNB per capita, esse país se destaca com o mais baixo nível de expectativa de vida ao nascer, pouco superior aos 54 anos. Sen também analisou a evolução da expectativa de vida na Grã-Bretanha, na primeira metade do século XX. O aumento muito pronunciado observado nesse período contrasta com o crescimento bastante lento do Produto Interno Bruto (PIB). Entre 1911 e 1921, o crescimento do PIB chegou a ser negativo. Os investimentos governamentais, mais que rendimentos individuais, foram cruciais para um aumento bastante expressivo na expectativa de vida britânica ${ }^{26}$.

Por outro lado, como indica o próprio Sen (2000), parece bastante claro que os processos vinculados à expansão na economia oferecem vantagens adicionais em relação à alternativa mediada pelo custeio público. O crescimento econômico pode, quando bem administrado, oferecer melhores condições à ampliação das diversas formas de liberdades humanas, uma vez que, por exemplo, a morte prematura, a morbidez acentuada ou as taxas de analfabetismo podem estar vinculadas aos baixos níveis de renda. Nessas circunstâncias, a elevação das rendas familiares pode ter reflexos imediatos nas condições de vida destas populações.

Mesmo assim, de acordo com Sen, a crença de que o desenvolvimento seja sempre dependente dos resultados do crescimento econômico reforça um falso dilema. Ao

\footnotetext{
${ }^{25}$ Freqüentes esforços do Sri Lanka e do estado indiano do Kerala ilustram bem os méritos dos gastos públicos com educação e saúde. Como aponta Sen (1993B), o Sri Lanka promoveu, desde início do século passado, uma maciça expansão de sistema de educação e saúde. Em 1940 o índice de mortalidade era de 20,6 em 1.000; em 1960 ele havia caído para 8,6 por 1.000 . No Kerala, que também investiu pesado na expansão dos serviços de educação e saúde, bem como na diminuição da pobreza (a despeito de seu PNB consideravelmente inferior à própria média indiana), a expectiva de vida, no início da década passada, era superior a 70 anos.

${ }^{26}$ Um das explicações plausíveis da rápida elevação da expectativa de vida na Grã-Betanha refere-se às mudanças no grau de compartilhamento social durante as décadas de guerra e nos aumentos no custeio público de serviços sociais, como custeio público nas áreas de nutrição e manutenção de serviços de saúde (Sen, 2000).
}

Cadernos do Leste

Artigos Cientificos

Belo Horizonte, Edição Especial, 2000 a 2008 
condicionar a expansão das oportunidades pessoais aos resultados econômicos, cria-se uma dependência que encoberta alguns encadeamentos ainda pouco percebidos. Até mesmo em economias mais pobres, em vários momentos e circunstâncias, pode ser mais prudente dar ênfase às várias disposições sociais, antes mesmo de quaisquer resultados positivos no crescimento da economia ${ }^{27}$. Nesse sentido,

"O problema talvez carecesse de interesse público se a prosperidade econômica se relacionasse estreitamente - numa correspondência aproximada de um para um - ao enriquecimento da vida das pessoas. Se tal fosse o caso, a busca da prosperidade econômica como um fim em si, embora errada no plano dos princípios, seria inseparável da busca de prosperidade como meio para o enriquecimento da vida das pessoas. Mas aquela correspondência estreita não se verifica. Países com altos PIBs per capita podem apresentar índices espantosamente baixos de qualidade de vida, como mortalidade prematura para a maioria da população, alta morbidade evitável, alta taxa de analfabetismo e assim por diante." (Sen, 1993A, p.314)

Ainda de acordo com esse mesmo autor,

"Não há dúvida de que a solidez econômica pode contribuir para que uma família obtenha uma melhor nutrição e um melhor atendimento médico. Mais do que isso, o crescimento econômico pode aumentar a capacidade do governo de oferecer educação pública, atendimento à saúde e nutrição. Só que os resultados do crescimento econômico nem sempre são canalizados para tais programas. (...) $\mathrm{O}$ ponto fundamental é que os países pobres não precisam esperar enriquecer para combater a mortalidade e elevar a expectativa de vida”. (Sen, 1993B. p.142)

Os argumentos expostos por Sen indicam sérias lacunas existentes entre as diversas interpretações e ações públicas que preconizam o crescimento econômico a qualquer custo. Não é incomum as propostas de políticas públicas ainda insistirem na velha retórica de "primeiro fazer crescer o bolo". Analisar e refletir a abrangência e os reais impactos do crescimento econômico é um desafio que não deve ser esquecido, principalmente em regiões

\footnotetext{
${ }^{27}$ Sen menciona o exemplo pioneiro ocorrido no Japão, onde o crescimento econômico foi dado por meio de um grande investimento nas chamadas oportunidades sociais, especialmente na área de educação básica. Às vezes se esquece que o Japão apresentava taxas de alfabetização mais elevadas do que as da Europa, mesmo na época da restauração Meiji em meados do século XIX, quando a industrialização ainda não ocorrera no país.
}

Cadernos do Leste

Artigos Cientificos

Belo Horizonte, Edição Especial, 2000 a 2008 
que ainda apresentam baixos níveis de renda ou desenvolvimento. Nesses casos, onde geralmente são escassos os recursos disponíveis, a construção de propostas alternativas e a elaboração de projetos realmente eficientes passam pela reavaliação de antigos pressupostos, vários deles presos apenas a alguns dos resultados econômicos.

\section{REFERÊNCIAS BIBLIOGRÁFICAS}

ALMEIDA Jr., J. M. Desenvolvimento ecologicamente auto-sustentável. Revista Humanidades.. Brasília: Ed. UNB. v.10, n.4, 1994.

BALDWIN, \& MEIER, Desenvolvimento econômico. São Paulo: Editora Mestre Jou, 1968.

BASTOS, V. \& SILVA, M. Para entender as economias do $3^{\circ}$ Mundo. Brasília: Editora UNB, 1995.

BRÜSEKE, F. J. O problema do desenvolvimento sustentável. In: CAVALCANTI, C. (org.). Desenvolvimento e natureza: estudos para uma sociedade sustentável. $2^{a}$ Ed. São Paulo: Cortez 1998.

CARDOSO, F. H. As idéias e o seu lugar: ensaios sobre as teorias do desenvolvimento. Petrópolis: Vozes, 1993.

COSTA, H. S. de M. Sustentabilidade urbana: um debate colocado em prática? Reflexões a partir de São Francisco/CA e sua área metropolitana. In: XI Encontro Nacional de Estudos Populacionais da ABEP, Caxambu: ABEP, 1998. p. 1735-1752.

COSTA, J. M. M. da. Reestruturação, desenvolvimento sustentável e desenvolvimento econômico. Cadernos IPPUR/UFRJ, Rio de Janeiro: Ippur/UFRJ, v. VIII, n.2/3, set/dez, 1994.

CROCKER, D. Qualidade de vida e desenvolvimento: o enfoque normativo de Sen e Nussbaum. Revista Lua Nova, São Paulo, n. 27/28, p.99-133, 1993.

Cadernos do Leste

Artigos Cientificos

Belo Horizonte, Edição Especial, 2000 a 2008 
EISENSTADT, S. N. Modernização e mudança social. Belo Horizonte: Editora do professor, 1968.

FURTADO, C. Teoria política do desenvolvimento. $8^{a}$ ed., São Paulo: Editora Nacional 1983.

O desenvolvimento: visão global. In: Pequena introdução ao desenvolvimento: enfoque interdisciplinar. São Paulo: Paz e Terra, 1980, p.1-13.

GUIMARÃES, R. P. O desafio político do desenvolvimento sustentado. Revista Lua Nova, São Paulo, n. 27/28, p.113-136, 1993.

HADDAD, P. Notas do organizador In: Haddad, P. (org) Economia regional; teorias e métodos de análise. Fortaleza: BNB ETENE, 1989.

HARPER, R. P. JR. Comparação da renda per capita e do índice de qualidade de vida material como medidas de desenvolvimento: o caso da América Latina. Estudos Econômicos/USP, São Paulo: USP, , v.2, n.14 p. 283-296, maio/ago. 1984.

JABOBI, P. Sustentabilidade socio-ambiental, participação e cidadania. In: XI Encontro Nacional de Estudos Populacionais da ABEP. Caxambu: ABEP, 1998, p. 3099-3110.

LEFF, E. Saber ambiental: sustentabilidad, racionalidad, complejidad, poder. Siglo Veintiuno Editores, 1998.

MATOS, R. E. S. (Coord.) Reestrututação sócio-espacial e desenvolvimento regional do Vale do Jequitinhonha. Belo Horizonte:UFMG/IGC/LESTE, 1999.

OLIVEIRA, F. A economia brasileira: crítica à razão dualista. $3^{a}$ ed. São Paulo: Editora Brasiliense, 1977.

RDH - PROGRAMA DAS NAÇÕES UNIDAS PARA O DESENVOLVIMENTO Desenvolvimento humano e condições de vida: indicadores brasileiros. Brasília, set., 1998.

RDH - PROGRAMA DAS NAÇÕES UNIDAS PARA O DESENVOLVIMENTO, O Paradigma Desenvolvimento Humano Sustentável. http://www.undp.org.br/desen..htm "Download" em 01/05/96.

RAMIRES, E. et. al. Economic growth and human development. World Development. v. 28, n. 2, 2000, p.197-219.

SACHS, I. Espaços, tempos e estratégias do desenvolvimento. São Paulo: Vértice, 1986.

SANTOS, A. V. dos S. O informe sobre o desenvolvimento no Brasil. In: http://www.iigov.org/pnud/bibliote/texto/bib10034.htm. "Download" em 19/04/96.

Cadernos do Leste

Artigos Cientificos

Belo Horizonte, Edição Especial, 2000 a 2008 
SEN, Amartya. Desenvolvimento como liberdade. São Paulo: Companhia das Letras, 2000. . Sobre ética e economia. São Paulo: Companhia das Letras, 1999.

. O desenvolvimento como expansão de capacidades. Revista Lua Nova, São Paulo, n. 27/28, p.313-333, 1993A.

. Economia da vida e da morte. Revista Brasileira de Ciências Sociais, n.23, ano 8, p. 138-145, out/nov, 1993B

SILVA, J. C. A. Desenvolvimento e meio ambiente. Fragmentos de Cultura. Goiânia: Instituto de filosofia e teologia de Goiás. Sociedade Goiana de Cultura. v.8, n.3, mai/jun 1998.

SINGER, P. Desenvolvimento e crise. $2^{\text {a }}$ ed. Rio de Janeiro: Paz e Terra, 1977.

SLIWIANY, R. M. Sociometria: como avaliar a qualidade de vida e projetos sociais. Petrópolis: Vozes, 1997

SOUZA, N. de J. Desenvolvimento econômico. 4ª Ed. São Paulo: Atlas, 1999.

SOUTO, A. L. S. et. al. Como reconhecer um bom governo?; O papel das administrações municipais na melhoria da qualidade de vida. Polis, São Paulo, 1999.

VEIGA, J. E. da A insustentável utopia do desenvolvimento. Seminário sobre a reestruturação do espaço urbano e regional do Brasil. CEDEPLAR/ANPUR: Ouro Preto, 15 e 16 de agosto de 1991 (sessão IV).

VIERA, P. F. A problemática ambiental e as ciências sociais no Brasil (1880-1990). In: VIERA, P. F. Dilemas socio-ambientais e desenvolvimento sustentável. Campinas: Editora UNICAMP, 1995.

UL HAQ, M. R Reflection on Development Human, Delhi/New York: Oxford University Press, 1996 
Cadernos do Leste Artigos Cientificos

Belo Horizonte, Edição Especial, 2000 a 2008 